\title{
In Vitro Evaluation of the Chemical Composition and Various Biological Activities of Ficus carica Leaf Extracts
}

\section{Ficus carica Yaprak Ekstrelerinin Kimyasal Bileşiminin ve Çeşitli Biyolojik Aktivitelerinin In Vitro Değerlendirilmesi}

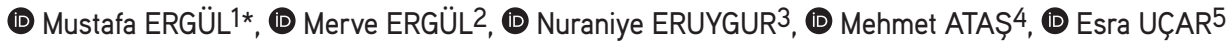 \\ 1Sivas Cumhuriyet University, Faculty of Pharmacy, Department of Biochemistry, Sivas, Turkey \\ 2Sivas Cumhuriyet University, Faculty of Pharmacy, Department of Pharmacology, Sivas, Turkey \\ 3Selçuk University, Faculty of Pharmacy, Department of Pharmacognosy, Konya, Turkey \\ 4 Sivas Cumhuriyet University, Faculty of Pharmacy, Department of Microbiology, Sivas, Turkey \\ 5 Sivas Cumhuriyet University, Sivas Vocational School, Department of Medicinal and Aromatic Plants, Sivas, Turkey
}

\begin{abstract}
Objectives: The present study aimed to investigate the inhibitory activities of enzymes related to diabetes mellitus and Alzheimer's disease of the methanol and water extracts of Ficus carica leaf extracts. The bioactive compounds and anticancer, antioxidant, and antimicrobial effects of the extracts were also investigated.

Materials and Methods: The bioactive compounds in the extracts were determined by gas chromatography-mass spectrometry. The antioxidant activity was evaluated by 1,1-diphenyl-2-picrylhydrazyl (DPPH), 2,2'-azino-bis(3-ethylbenzothiazoline-6 sulphonic acid) (ABTS) radical scavenging, total phenol and flavonoid content, ferric reducing power, and iron chelating method. The anticancer, anticholinesterase, and antimicrobial effects were investigated using the XTT assay, Ellman method, and microdilution, respectively.

Results: Our results showed that between the water and methanol extracts there was a difference in terms of chemical composition. The antioxidant results suggested that both extracts have strong antioxidant activity. Similarly, both extracts showed strong $\alpha$-glucosidase and $\alpha$-amylase inhibition activity, while the water extract had higher inhibition activity than the methanol extract against acetylcholinesterase and butyrylcholinesterase. The methanol extract of $F$. carica exhibited significant anticancer activity on MDA-MB-231 cells and showed moderate antimicrobial activities against Escherichia coli and Staphylococcus aureus.
\end{abstract}

Conclusion: Our results suggest that $F$. carica leaves could be a valuable source for developing a promising therapeutic agent in cancer, diabetes, and Alzheimer's disease.

Key words: Ficus carica, Alzheimer's disease, diabetes, antioxidant activity, anticancer and antimicrobial activities

öz

Amaç: Bu çalıșmada, Ficus carica yapraklarına ait su ve metanol ekstrelerinin diyabet ve Alzheimer hastalığı ile ilișkili enzimlerin inhibisyonu üzerine etkisinin araştırılması amaçlanmıştır. Ayrıca, ekstrelere ait biyoaktif bileșenler, antikanser, antioksidan ve antimikrobiyal etkiler de araştırılmıştır.

Gereç ve Yöntemler: Ekstrelerdeki biyoaktif bileșikler gaz kromatografisi-kütle spektrometresi metodu ile belirlenmiștir. Antioksidan aktivite, 1,1-diphenyl-2-picrylhydrazyl (DPPH), 2,2'-azino-bis(3-ethylbenzothiazoline-6 sulphonic acid) (ABTS) radikal süpürücü, toplam fenol ve flavonoid içeriği, ferrik indirgeme gücü ve demir şelasyon yöntemleriyle değerlendirilmiştir. Antikanser, antikolinesteraz ve antimikrobiyal etkinlikler ise sırasıyla XTT yöntemi, Ellman yöntemi ve mikrodilüsyon tekniği yöntemi ile belirlenmiştir.

Bulgular: Elde ettiğimiz sonuçlar su ve metanol ekstreleri arasında kimyasal bileşim açısından farklılık olduğunu ve her iki ekstrenin de güçlü antioksidan aktiviteye sahip olduğunu göstermiștir. Benzer şekilde, her iki ekstrede güçlü $\alpha$-glikozidaz ve $\alpha$-amilaz aktivite gösterirken, su ekstresi metanole göre daha güçlü asetilkolinesteraz ve butirilkolinesteraz inhibisyon etkiye sahiptir. F. carica metanol ekstresi MDA-MB-231 hücreleri üzerinde güçlü antikanser etki, Escherichia coli ve Staphylococcus aureus'e karşı ise orta düzeyde antimikrobiyal etki göstermiştir.

Sonuç: Bulgularımız, F. carica yapraklarının kanser, diyabet ve Alzheimer hastalığında umut verici bir terapötik ajan geliştirmek için değerli bir kaynak olabileceğini düșündürmektedir.

Anahtar kelimeler: Ficus carica, Alzheimer hastalığı, diyabet, antioksidan aktivite, antikanser ve antimikrobiyal aktivite

*Correspondence: E-mail: m.ergul@yahoo.com.tr, Phone: ++90 5556914667 ORCID: orcid.org/0000-0003-4303-2996

Received: 20.06.2018, Accepted: 25.07.2018

Turk J Pharm Sci, Published by Galenos Publishing House. 


\section{INTRODUCTION}

Ficus carica $\mathrm{L}$. belongs to the family Moraceae and is a native of southwest Asia. It is cultivated worldwide and has been traditionally used in indigenous systems of medicine, such as Ayurveda and homeopathy, for cardiovascular and hypertensive diseases., ${ }^{1,2}$ Its fruit possesses several vitamins, minerals, carbohydrates, and phenolic compounds, for instance, phenolic acids, flavonols, and flavones, which play a significant role in its therapeutic efficiency. ${ }^{3-5}$ Many reports also stated that the polyphenolic ingredient of the fruit has anti-inflammatory, antioxidant, antimicrobial, and anticancer effects. ${ }^{6}$

In recent years, due to increasing cancer cases and similar health problems, the demand for products with antioxidant properties has been increasing day by day. In this context, plants that have antioxidant and anticancer properties have attracted wide attention. It is well known that antioxidants have significant inhibitory effects on various free radical species and also neutralize nonradical species such as hydrogen peroxide. Additionally, they can prevent the production of many reactive oxygen species in various diseases such as cancer and diabetes. ${ }^{7,8}$

Diabetes mellitus is a chronic metabolic disease that causes elevation of blood sugar due to insufficient insulin secretion or insulin resistance. $\alpha$-Glucosidase and $\alpha$-amylase inhibitors are used in some cases to control the level of postprandial blood glucose in the treatment of diabetes mellitus. These two enzymes are involved in the conversion of food polysaccharides into monosaccharides. However, synthetic hypoglycemic agents have been reported for several side effects such as hepatotoxicity and gastrointestinal disorders. Accordingly, researchers are looking for new potential antidiabetic agents from natural sources with less adverse effects. ${ }^{9}$

Alzheimer's disease (AD) is the most common form of dementia, characterized by memory loss and other cognitive disabilities. Down-regulation of acetylcholine is associated with the development of AD. Acetylcholinesterase (AChE) and butyrylcholinesterase (BChE) are responsible for the hydrolytic metabolism of the neurotransmitter acetylcholine (ACh) into choline and acetate in the brain. Based on the cholinergic hypothesis, a defect in the cholinergic system is involved in the development of $A D .^{10}$ Therefore, the current treatment strategy for $A D$ is directed to the inhibition of $A C h E$ and BChE. There are some $A C h E$ inhibitors such as galantamine, physostigmine, and tacrine approved for the treatment of AD. However, these drugs have side effects, including hepatotoxicity, limiting the use of these drugs in clinical practice. Hence, researchers are looking for new treatments to control the disease and improve the quality of life for people with $A D$ from natural resources.

Cancer is one of the most significant health issues worldwide and the second leading cause of death globally after cardiovascular diseases." Conventional treatments used in the clinic such as chemotherapy, surgery, and radiotherapy have several serious side effects and can cause damage to noncancerous tissues. ${ }^{12}$ Moreover, due to increasing drug resistance especially in cancer treatment, plants have become increasingly important in the search for new chemotherapeutic agents. In the clinic, there are many antitumor drugs derived from plants such as vincristine, vinblastine (Catharanthus sp.), paclitaxel (Taxus sp.), and epipodophyllotoxins (Podophyllum sp.). ${ }^{13}$ Furthermore, research continues at a great pace for the discovery of new drugs with more effective and less side effect profiles. $F$. carica is one of the medicinally important plants with therapeutic potential. Many researchers have reported the antimicrobial effects of $F$. carica leaf extracts against oral bacteria, nosocomial infectious agents, food poisoning bacteria, fungi, and viruses. ${ }^{14-17}$ Moreover, the fruit, root, and leaves of $F$. carica are utilized medicinally for treating various diseases as a respiratory, gastrointestinal, anti-inflammatory, and antispasmodic remedy. ${ }^{18}$

To the best of our knowledge, the fruit and different parts of this plant have been mostly studied, and the number of study on the leaves is limited. Thus, this study was carried out to evaluate differences between water and methanol extracts for antioxidant, antimicrobial, enzyme inhibition activity (AChE, BChE, $\alpha$-glucosidase, and $\alpha$-amylase), and anticancer properties in vitro. It was also aimed to analyze the content of extracts by gas chromatography-mass spectroscopy (GC-MS).

\section{EXPERIMENTAL}

This study was conducted in the laboratories of the Faculty of Pharmacy, Sivas Cumhuriyet University, Sivas, in 2018. The plant materials were collected in July 2017 from the wild flora of Saklıkent/Fethiye. The experiments were performed in a completely randomized design with three replications.

\section{Preparation of extracts}

The plant leaves were milled with a grinder and then dried in the shade and the dry leaves were ground in a blender (Blue house). Ten grams of the leaf was soaked in $50 \mathrm{~mL}$ of methanol (Sigma) and water for $24 \mathrm{~h}$ with intermittent shaking. At the end of the extraction, it was filtered through No. 1 Whatman filter paper. The filtrate was concentrated to dryness under reduced pressure in a rotary evaporator at $40^{\circ} \mathrm{C}$ and this was repeated three times. The obtained extracts were analyzed using GCMS.19

\section{In vitro antioxidant activity}

The antioxidant activity of the methanol and water extracts of $F$. carica leaves was tested using different methods, namely $\mathrm{DPPH}, \mathrm{ABTS}$ radical scavenging activity, total phenol/flavonoid content, ferric reducing power, and iron chelating method.

\section{DPPH radical scavenging activity}

The free radical scavenging activity by methanol extracts was determined according to the method reported by Miser Salihoglu et al. ${ }^{20}$ First $150 \mu \mathrm{L}$ of the extract was mixed with $50 \mu \mathrm{L}$ of $1.0 \times 10^{-3} \mathrm{M}$ freshly prepared DPPH• methanol solution in 96-well plates. Methanol was used as the control of the experiment. After 30 min of incubation at $25^{\circ} \mathrm{C}$, the reduction of the DPPH was measured reading the absorbance at $517 \mathrm{~nm}$ with a microplate reader (Epoch, USA). Butylated hydroxytoluene (BHT) was used for the positive controls and the percentage inhibition was calculated with the following equation: 
\% Inhibition=[Absorbance of control-Absorbance of test sample/Absorbance of control]×100

\section{ABTS radical scavenging activity}

For determining the ABTS radical scavenging activity of the extracts, the method described by Re et al. ${ }^{21}$ was followed with slight modification. The stock solution of ABTS was made by reacting $7 \mathrm{mM}$ ABTS solution with $2.4 \mathrm{mM}$ potassium persulfate solution in equal volume for $16 \mathrm{~h}$. The working solution was then prepared by diluting the stock ABTS $\bullet^{+}$solution with methanol to give an absorbance of $0.7 \pm 0.02$ units at $734 \mathrm{~nm}$ using a microplate reader (Epoch, USA). In each experiment, the ABTS $\bullet^{+}$solution was prepared freshly. Fifty microliters of the extract was mixed with $150 \mu \mathrm{L}$ of $\mathrm{ABTS} \bullet^{\bullet+}$ working solution and the resulting mixture was left for $10 \mathrm{~min}$ in a dark place. All the analyses were conducted in triplicate and the results expressed as the mean \pm standard deviation. Appropriate blanks (methanol) and standard (BHT) were run simultaneously.

\section{Determination of total phenolic content (TPC)}

In order to measure the TPC in the extracts, the spectrophotometric Folin-Ciocalteu method was used as previously described by Clarke et al., ${ }^{22}$ with slight modification. Briefly, $20 \mu \mathrm{L}$ of extract in DMSO was mixed with $100 \mu \mathrm{L}$ of freshly $1 / 10$ diluted $\mathrm{F}-\mathrm{C}$ reagent with distilled water. After $5 \mathrm{~min}$, the solution was mixed with $80 \mu \mathrm{L}$ of $7.5 \% \mathrm{Na}_{2} \mathrm{CO}_{3}$ solution, and incubated for $30 \mathrm{~min}$ at $25^{\circ} \mathrm{C}$. The measurement of absorbance was performed at $650 \mathrm{~nm}$ in a microplate reader (Epoch, USA). All the analyses were performed in triplicate and the results expressed as the mean \pm standard deviation (SD). Appropriate blanks (DMSO) and standard (gallic acid in DMSO) were run simultaneously, after which the TPC was calculated as milligrams gallic acid equivalents per gram of dry extract.

\section{Estimation of total flavonoid content (TFC)}

For determination of TFC, the aluminum chloride colorimetric method was used as previously described by Molan and Mahd ${ }^{23}$ using catechin as the reference standard. Briefly, $25 \mu \mathrm{L}$ of 1 $\mathrm{mg} / \mathrm{mL}$ test sample solution, $100 \mu \mathrm{L}$ of $\mathrm{dd}$. $\mathrm{H}_{2} \mathrm{O}$, and $7 \mu \mathrm{L}$ of $5 \%$ $\mathrm{NaNO}_{2}$ were mixed together in 96-well plates. After 15 min of incubation at room temperature, $7 \mu \mathrm{L}$ of $10 \% \mathrm{AlCl}_{3}$ was added. After $5 \mathrm{~min}, 50 \mu \mathrm{L}$ of $1 \mathrm{M} \mathrm{NaOH}$ and $60 \mu \mathrm{L}$ of distilled water were added to each well. Then the absorbance was measured at 490 $\mathrm{nm}$ in a microplate reader (Epoch, USA). All determinations were carried out in triplicate. The content of total flavonoids was expressed as milligrams of catechin equivalent per gram of the dry weight of the extract.

\section{Iron chelating activity}

The iron chelating activity of the extracts was determined according to their interaction with the formation of the ferrozine$\mathrm{Fe}^{2+}$ complex. Previously described procedures were used. ${ }^{24}$ Briefly, a mixture of $200 \mu \mathrm{L}$ of $0.1 \mathrm{mM} \mathrm{FeSO}_{4}, 200 \mu \mathrm{L}$ of extract, and $400 \mu \mathrm{L}$ of $0.2 \mathrm{mM}$ ferrozine was allowed to react at $25^{\circ} \mathrm{C}$. The mixture absorbance was read after $10 \mathrm{~min}$ of incubation at $562 \mathrm{~nm}$. EDTA was used as positive control.

\section{Ferric reducing antioxidant power (FRAP) assay}

The FRAP reagent is used as a reducing agent in redox colorimetric reactions of antioxidants. The FRAP assay was conducted according to the previously reported method with a slight modification. ${ }^{25,26}$ The stock solution of each extract was prepared in DMSO. The working solution of FRAP reagent was prepared by mixing $0.3 \mathrm{M} \mathrm{pH} 3.6$ acetate buffer and a solution of $10 \mathrm{mM}$ 2,4,6-tripyridyl-s-triazine (TPTZ) in $0.04 \mathrm{M} \mathrm{HCl}$ and $0.02 \mathrm{M} \mathrm{FeCl}_{3}$ solution in the ratio of 10:1:1 at the time of use. All solutions were prepared fresh on the day of the experiment. Thirty microliters of the sample solution and $270 \mu \mathrm{L}$ of FRAP working solution were mixed together in 96-well plates and warmed at $37^{\circ} \mathrm{C}$ for $4 \mathrm{~min}$. All determinations were performed in triplicate. The absorbance was measured at $593 \mathrm{~nm}$. A standard calibration curve was prepared using different concentrations of $\mathrm{FeSO}_{4}$ solution. The results were expressed as FRAP values.

\section{Acetylcholinesterase/butyrylcholinesterase inhibition assay}

The assay was carried out according to the Ellman method ${ }^{27}$ as follows. The mixture consisting of $20 \mu \mathrm{L}$ of test sample/ reference standard of various concentrations, $140 \mu \mathrm{L}$ of 0.1

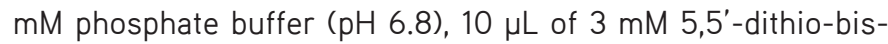
nitrobenzoic acid (DTNB), and $20 \mu \mathrm{L}$ of enzyme $(0.22 \mathrm{U} / \mathrm{mL}$ for acetylcholinesterase/0.1 $\mathrm{U} / \mathrm{mL}$ for butyrylcholinesterase) prepared in phosphate buffer was incubated for $5 \mathrm{~min}$ at $25^{\circ} \mathrm{C}$. Following preincubation, $10 \mu \mathrm{L}$ of the substrate $0.71 \mathrm{mM}$ acetylthiocholine iodide/0.2 $\mathrm{mM}$ butyrylthiocholine chloride in phosphate buffer) was added to start the reaction, followed by further incubation for $10 \mathrm{~min}$. The developed yellow color was measured at $412 \mathrm{~nm}$ (Epoch, USA). Galantamine was used as the positive control.

\section{Alpha-glucosidase inhibition activity}

The $\alpha$-glucosidase inhibition method was reported by Kumar et al. ${ }^{28}$ Acarbose was used as a positive control, while phosphate buffer was used as a negative control in place of the sample. Each concentration was carried out in triplicate. Twentyfive microliters of sample solution diluted with buffer was mixed with $25 \mu \mathrm{L}$ of $\alpha$-glucosidase $(0.5 \mathrm{U} / \mathrm{mL})$ and incubated for approximately $10 \mathrm{~min}$ at $25^{\circ} \mathrm{C}$. Then $25 \mu \mathrm{L}$ of $0.5 \mathrm{mM}$ 4-nitrophenyl- $\beta$-D-glucuronide ( $p N P G$ ) was added to each well as substrate and incubated for a $30 \mathrm{~min}$ at $37^{\circ} \mathrm{C}$. After the incubation period, $100 \mu \mathrm{L}$ of $0.2 \mathrm{M}$ sodium carbonate was added to terminate the reaction and the absorbance was read at 405 $\mathrm{nm}$.

\section{Alpha-amylase inhibition activity}

The $\alpha$-amylase inhibition method was reported by Kumar et al. ${ }^{29}$ Acarbose was used as a positive control, while phosphate buffer (0.02 M PBS, $\mathrm{pH}$ 6.9) was used as a negative control in place of the sample. Each sample was tested in triplicate with different concentrations. The reaction mixture containing $50 \mu \mathrm{L}$ of sample solution diluted with buffer and $25 \mu \mathrm{L}$ of $\alpha$-amylase from porcine pancreases $(0.5 \mathrm{mg} / \mathrm{mL})$ was incubated for approximately $10 \mathrm{~min}$ at $25^{\circ} \mathrm{C}$. Then $50 \mu \mathrm{L}$ of freshly prepared $0.5 \%$ starch solution ( $\mathrm{w} / \mathrm{v}$ ) was added to each well as substrate and incubated for $10 \mathrm{~min}$ at $25^{\circ} \mathrm{C}$. After the incubation period, 
$100 \mu \mathrm{L}$ of $1 \%$ 3,5-dinitrosalicylic acid (DNS) was added as the color reagent, followed by heating in a water bath for $10 \mathrm{~min}$. The absorbance was read at $540 \mathrm{~nm}$.

\section{Antimicrobial activity}

\section{Microdilution broth method}

The microdilution broth method with slight modification was used to determine the minimum inhibitory concentration (MIC) of the water and methanol extracts of $F$. carica against the microorganism. ${ }^{30}$ In the present study, Staphylococcus aureus (ATCC 29213), Enterococcus faecalis (ATCC 29212), Pseudomonas aeruginosa (ATCC 27853), Escherichia coli (ATCC 25922), Klebsiella pneumoniae (ATCC 13883), and Candida albicans (ATCC 10231) strains were used. The extracts were dissolved in $50 \%$ dimethyl sulfoxide (DMSO) and the final concentrations of the extracts were $50 \mathrm{mg} / \mathrm{mL}$. Mueller Hinton Broth (Accumix ${ }^{\circledR}$ AM1072) and Sabouraud Dextrose Broth (Himedia ME033) were used for dilution bacteria and $C$. albicans cultures, respectively. In the first row of the plate, $90 \mu \mathrm{L}$ of broth was added to the wells and $50 \mu \mathrm{L}$ of broth was added to all other wells. The $11^{\text {th }}$ wells were used as the reproductive controls and $100 \mu \mathrm{L}$ of broth was added. In the first line of the microtiter plate, $10 \mu \mathrm{L}$ of extract was added and serial two-fold dilutions were prepared from the diluted extracts to give concentrations ranging from 2.5 to $0.004 \mathrm{mg} / \mathrm{mL}$. The bacteria and fungi suspensions ( 50 $\mu \mathrm{L}$ ) were added to prepared samples. The final inoculum size was $5 \times 10^{5} \mathrm{CFU} / \mathrm{mL}$ in the bacteria wells and $0.5-2.5 \times 10^{3} \mathrm{CFU} /$ $\mathrm{mL}$ in the $C$. albicans wells (CLSI, 2002, CLSI, 2012). The plates with the added bacteria and $\mathrm{C}$. albicans were incubated at $37^{\circ} \mathrm{C}$ and $35^{\circ} \mathrm{C}$ for $16-24 \mathrm{~h}$, respectively. Afterwards, to observe microbial growth, $50 \mu \mathrm{L}$ of 2,3,5-triphenyltetrazolium chloride (TTC) (Merck, Germany) was added to each well. The microtiter plates were further incubated at $37^{\circ} \mathrm{C}$ for $2 \mathrm{~h}$. The first well in which the density of formazan's red color was reduced was accepted as showing the MIC. The experiment was performed in duplicate and the standard deviation was zero.

\section{Cytotoxicity}

\section{Cell lines and reagents}

Human breast adenocarcinoma (MDA-MB-231) cells and mouse fibroblast (L929) cells were obtained from the American Type Culture Collection (ATCC, Manassas, VA, USA). Dulbecco's modified Eagle's medium (DMEM), fetal bovine serum (FBS), and sterile phosphate buffer saline (PBS) were purchased from PAA Ltd. (France). Trypsin-EDTA was supplied from Biological Industries Ltd. (Haemek, Israel). DMEM without phenol red and L-glutamine-penicillin-streptomycin solutions were from Sigma-Aldrich (Steinheim am Albuch, Germany). XTT reagent (2,3-bis-(2-methoxy-4-nitro-5-sulfophenyl)-2H-tetrazolium-5carboxanilide) was purchased from Roche Diagnostics.

\section{Cell culture}

The cytotoxicity of the $F$. carica leaf extracts was tested against MDA-MB-231 and L929 cell lines. During the experiments, both cell lines were grown in DMEM supplemented with $10 \%$ FBS, $1 \%$ L-glutamine, $100 \mathrm{IU} / \mathrm{mL}$ penicillin, and $10 \mathrm{mg} / \mathrm{mL}$ streptomycin in $25 \mathrm{~cm}^{2}$ polystyrene flasks and maintained in a humidified atmosphere with $5 \% \mathrm{CO}_{2}$ at $37^{\circ} \mathrm{C}$. Growth and morphology were monitored, the culture medium was changed every 2 days, and the cells were passaged when they had reached $80-90 \%$ confluence.

\section{Cell viability assay}

The antiproliferative activity of the $F$. carica leaf extracts was evaluated by XTT colorimetric assay against the MDA-MB-231 and L929 cells. Extracts were dissolved in DMSO and diluted in DMEM prior to treatment. Initially, cancer and control cells were seeded at a density of $5 \times 10^{3}$ cells per well in 96 -well culture plates in $100 \mu \mathrm{L}$ of culture medium and were allowed to attach overnight before treatment. The next day, these cells were treated with serial concentrations $(0.0625,0.125,0.25,0.5,1$ $\mathrm{mg} / \mathrm{mL}$ ) of $F$. carica for $24 \mathrm{~h}$. Furthermore, nontreated cells and cells treated with DMSO $(0.5 \%)$ were used as negative controls and solvent controls, respectively. After that, the treatment medium was removed and wells were washed twice with 200 $\mu \mathrm{L}$ of PBS. At the end of these periods, for determination of living cells, $100 \mu \mathrm{L}$ of DMEM without phenol red and $50 \mu \mathrm{L}$ of XTT labeling mixture were added to each well and then the plates were incubated for another $4 \mathrm{~h}$. The absorbance of XTTformazan was measured using a microplate reader (Epoch, USA) at $450 \mathrm{~nm}$ against the control (the same cells without any treatment). All experiments were performed in three independent experiments and cell viability was expressed in \% related to the control (100\% viability).

\section{Statistical analysis}

Data obtained from in vitro antioxidant and antidiabetic activity were expressed as the mean $\pm \mathrm{SD}$. Cytotoxicity results were evaluated statistically using one-way analysis of variance (ANOVA) at $95 \%$ confidence levels for multiple comparisons. The Tukey test was used as the post-hoc test. $P$ values less than or equal to 0.05 were considered to be statistically significant. The 50\% inhibitory concentrations of the extract and reference compounds were calculated through an extract dose-response curve in GraphPad Software (San Diego, CA, USA).

\section{RESULTS AND DISCUSSION}

GC-MS analysis of the water and methanol extracts of F. carica The chemical compositions of the water and methanol extracts of $F$. carica leaves were studied using GC-MS and the results are shown in Table 1. According to the GC-MS results, more different components were obtained in the methanol extract than in the aqueous extract of $F$. carica. Namely, six and 28 different compounds were determined in the water and methanol extracts, respectively. While the most abundant components are benzene, methoxy-(3.32\%), 4-methyl-1,4heptadiene (6.85\%), 1-pentene, 2,3-dimethyl-(2.72\%) for the water extract, they were $2 \mathrm{H}$-furo[2,3-H]-1-benzopyran-2-one (53.64\%), bergapten $(19.27 \%), 9,12,15$-octadecatrienoic acid, methyl ester, $(Z, Z, Z)-(4.05 \%)$ for the methanol extract. 
Table 1. Chemical components of the water and methanol extracts from $F$. carica

Chemical components RT Water Methanol (min) (\%) (\%)

2-Furanmethanol (CAS)

6.692

--- $\quad 0.36$

2-Cyclopentene-1,4-dione

7.493 0.10

Benzene, methoxy-

8.654

3.3

1,2-Cyclopentanedione

$8.849 \quad---\quad 0.31$

Phenol (CAS)

$\begin{array}{lll}11.298 & -0.02 \quad 0.14\end{array}$

4H-Pyran-4-one, 2,3-dihydro-3,5-

16.677

$---$

0.30

dihydroxy-6-methyl-

4-Methyl-1,4-heptadiene

1-Pentene, 2,3-dimethyl-

2-Furancarboxaldehyde,

$17.031 \quad 6.85 \quad---$
18.576

2.72

19.274

$---$

0.01

5-Acetyl-2-furanmethanol

$20.545 \quad 1.13$

Benzoic acid, 3-hydroxy-, methyl ester (CAS)

\begin{tabular}{|c|c|c|c|}
\hline Cyclododecane & 28.218 & --- & 0.66 \\
\hline 2,7-Naphthalenediol (CAS) & 28.630 & --- & 0.82 \\
\hline Phenol, 2,4-bis(1,1-dimethylethyl)- & 29.288 & --- & 0.64 \\
\hline 1H-Imidazole, 4-methyl-5-nitro- & 30.827 & --- & 0.10 \\
\hline 6,7-Dimethoxyquinoxaline & 31.931 & --- & 0.10 \\
\hline acrylic acid dodecanyl ester & 33.436 & --- & 0.69 \\
\hline (-)-Loliolide & 35.084 & --- & 0.48 \\
\hline 2H-Furo[2,3-H]-1-benzopyran-2-one & 36.280 & --- & 53.64 \\
\hline 7H-Furo[3,2-g][1]benzopyran-7-one & 36.640 & --- & 0.10 \\
\hline Hexadecanoic acid, methyl ester & 37.705 & --- & 0.66 \\
\hline Hexadecanoic acid (CAS) & 38.357 & --- & 2.30 \\
\hline Bergapten & 40.114 & --- & 19.27 \\
\hline $\begin{array}{l}\text { 9,12,15-Octadecatrienoic acid, } \\
\text { methyl ester (CAS) }\end{array}$ & 40.526 & --- & 0.80 \\
\hline $\begin{array}{l}\text { 7-Oxabicyclo[4.1.0]heptane, } \\
\text { 1,5-dimethyl- }\end{array}$ & 40.709 & --- & 1.40 \\
\hline $\begin{array}{l}\text { Heptadecanoic acid, 16-methyl-, } \\
\text { methyl ester }\end{array}$ & 40.886 & --- & 0.10 \\
\hline $\begin{array}{l}\text { 9,12,15-Octadecatrienoic acid, } \\
\text { methyl ester, }(Z, Z, Z) \text { - }\end{array}$ & 41.207 & --- & 4.05 \\
\hline $\begin{array}{l}\text { Methyl }(Z)-5,11,14,17- \\
\text { eicosatetraenoate }\end{array}$ & 41.424 & --- & 0.10 \\
\hline Ferruginol & 43.970 & --- & 0.28 \\
\hline $\begin{array}{l}\text { 4,8,12,16-Tetramethylheptadecan-4- } \\
\text { olide }\end{array}$ & 44.176 & --- & 0.11 \\
\hline Isosteviol methyl ester & 45.899 & --- & 0.38 \\
\hline $\begin{array}{l}\text { Docosa-2,6,10,14,18-pentaen-22-al, } \\
\text { 2,6,10,15,18-pentamethyl-, alltrans }\end{array}$ & 51.272 & --- & 1.07 \\
\hline Vitamin $\mathrm{E}$ & 55.563 & --- & 0.35 \\
\hline
\end{tabular}

When the extracts of the $F$. carica leaves were compared, we can see that the solubility of the methanol extracts was much greater than that of the water extracts, because the number of components is much higher in the methanol extracts. However, when we compare the enzyme inhibition activities, the water extracts showed higher inhibition activities than the methanol extracts (Table 2). This is most likely caused by the water extracts' components. It is also interesting that almost none of these components are present in the methanol extract. Likewise, in the study conducted by Konyalıoğlu, ${ }^{31}$ the amount of alpha-tocopherol in fig leaves was determined by HPLC and correlated with antioxidant activity. In our study, GCMS analysis of the $F$. carica leaves shows that the antioxidant vitamin alpha-tocopherol (vitamin E) was found in the methanol extract.

\section{In vitro antioxidant activity}

\section{In vitro radical scavenging activity}

In some physiopathologic circumstances, there is excessive production of free radicals, leading to the occurrence of oxidative stress. This later is related to the appearance of many diseases including Alzheimer's diseases, cardiovascular disease, and cancer. ${ }^{7,8}$ Natural antioxidants inhibit their activity by different mechanisms such as scavenging of reactive oxygen species, metal chelating, activation of antioxidant enzymes, and inhibition of oxidase. Therefore, it is necessary to use different methods to evaluate the antioxidant activity of extracts in plants. Previous studies have shown that the fig of $F$. carica has antioxidant activity. ${ }^{32}$ In our study, leaf extract of $F$. carica scavenged DPPH and ABTS radicals in a concentration-dependent manner. As shown in Figure $1 \mathrm{a}$ and $1 \mathrm{~b}$, the $\mathrm{IC}_{50}$ of ABTS radical scavenging activity of the methanol and water extract was $559.39 \mu \mathrm{g} / \mathrm{mL}$ and $428.51 \mu \mathrm{g} / \mathrm{mL}$, while DPPH scavenging activity was 1.45 $\mathrm{mg} / \mathrm{mL}$ and $1.83 \mathrm{mg} / \mathrm{mL}$, respectively.

The total phenolics (mg GAE/g of sample) and flavonoid (mg $\mathrm{CE} / \mathrm{g}$ of sample) in the different extract of the $F$. carica leaves are exhibited in Figure 1c. F. carica leaf methanol extract (16.11 mg GAE/g) exhibited higher phenolic contents as compared to water extract (6.29 mg GAE/g), while the total flavonoid content was almost the same as that of methanol (11.29 mg CE/g) and water (11.06 mg CE/g) extract. The phenolic compounds in fig leaves were quantitatively determined using HPLC-DAD by

Table 2. Enzyme inhibitory activity (\%) of the water and methanol extracts from $F$. carica leaves (at $2 \mathrm{mg} / \mathrm{mL}$ concentrations)

$$
\text { Anticholinesterase activity Antidiabetic activity }
$$

\begin{tabular}{lllll}
\hline Extracts & AChE & BChE & $\alpha$-glucosidase & $\alpha$-amylase \\
\hline Methanol & $53.33 \pm 3.21$ & $57.97 \pm 5.61$ & $64.93 \pm 1.09$ & $67.32 \pm 2.46$ \\
\hline Water & $62.88 \pm 3.65$ & $73.02 \pm 4.28$ & $69.56 \pm 0.61$ & $69.08 \pm 6.05$
\end{tabular}

\section{Reference drugs}

\begin{tabular}{lllll}
$\begin{array}{l}\text { Galantamine } \\
\text { hydrobromide }\end{array}$ & $93.87 \pm 0.56$ & $89.89 \pm 0.01$ & --- & --- \\
\hline Acarbose & --- & --- & $57.56 \pm 0.52$ & $58.40 \pm 0.63$ \\
\hline
\end{tabular}

AChE: Acetylcholinesterase, BChE: Butyrylcholinesterase 
Teixeira et al. ${ }^{33}$ We also achieved similar results using a different method in our study. In another study, by Ali et al., ${ }^{34}$ it was shown that antioxidant and anti-inflammatory activities of fig leaves are associated with flavonoids and phenolic compounds found in the leaves.

It is well known that the ferrous and cupric ions stimulate lipid oxidation by breaking down hydrogen and lipid peroxides to reactive free radicals via the Fenton reaction. Therefore, metal chelating agents play an important role in terms of retarding the radical degradation by reducing the concentration of transition metal. ${ }^{35}$ According to our results, water extracts exhibited better iron chelating activity than methanol extract (Figure 1e).

In the FRAP assay, the reductants (antioxidants) present in the extract reduce a $\mathrm{Fe}^{3+}-\mathrm{TPTZ}$ complex to form blue $\mathrm{Fe}^{2+}-\mathrm{TPTZ}$. The change in absorbance at $593 \mathrm{~nm}$ is proportional to the FRAP value of the antioxidants in the sample. ${ }^{36}$ The results of the FRAP assay are given in Figure 1d. In this assay, the higher activity was noted for methanol extract than water extract at higher concentration, but the ferric reducing power was the same at the lower concentration.

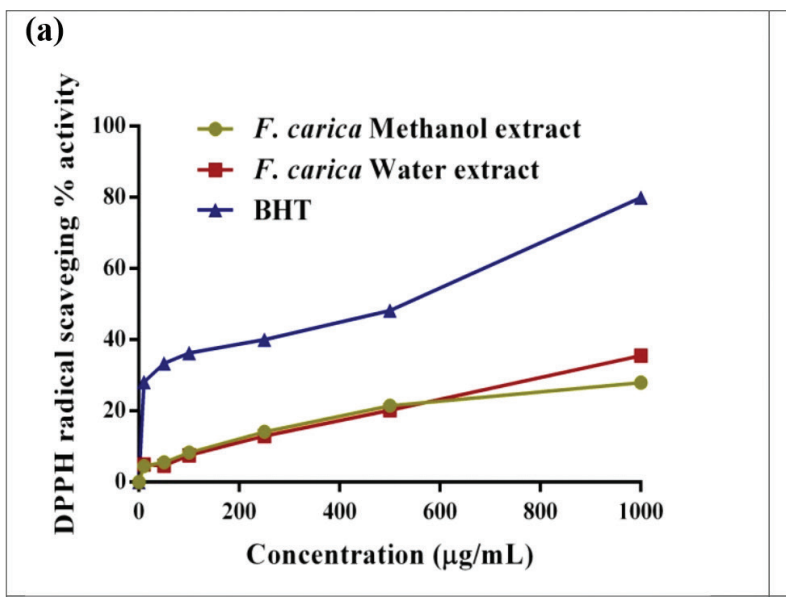

(c)

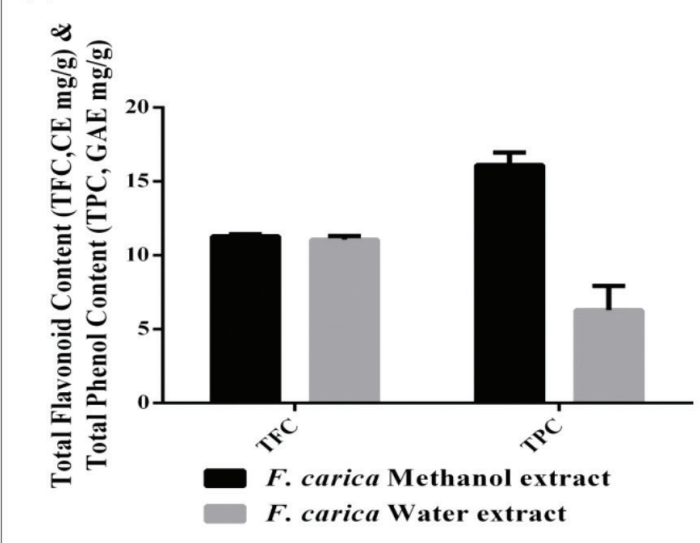

(b)

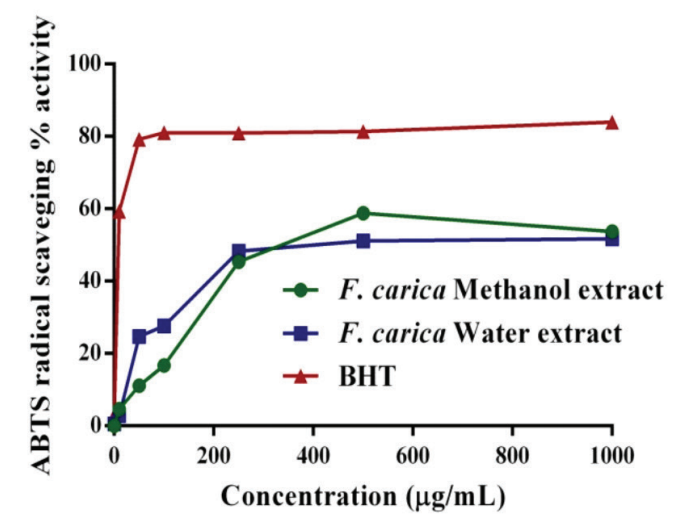

(d)

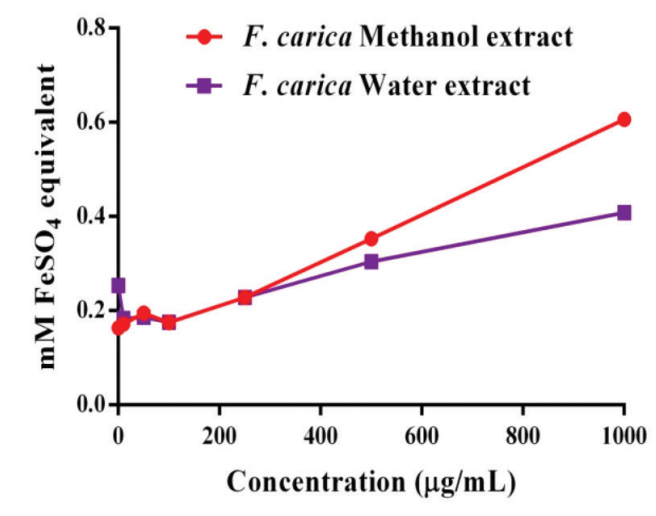

(e)

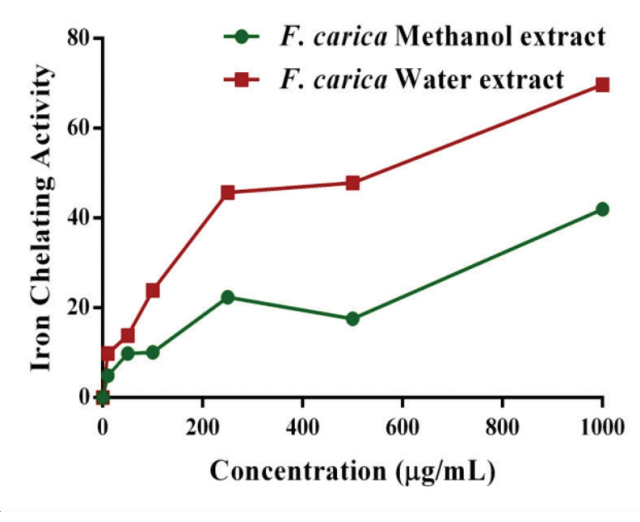

Figure 1. In vitro antioxidant activity of the methanol and water extracts from F. carica leaves; a) DPPH radical scavenging activity; b) ABTS radical scavenging activity; c) total phenol and total flavonoid contents; d) ferric reducing power as $\mathrm{FeSO}_{4}$ equivalent; e) iron chelating activity. 


\section{AChE and BChE inhibition activity}

The methanol and water extracts prepared from $F$. carica leaves were evaluated for their inhibitory effects against AChE and $\mathrm{BChE}$, which are Alzheimer's disease-related enzymes. The water extract exhibited stronger activity and showed $63 \%$ and $73 \%$ inhibition of $\mathrm{AChE}$ and BChE, which was lower than the standard drug galantamine (with 93\% and 90\% inhibition) at the same concentration (Table 2). According to the report by Ahmad et al. ${ }^{37}$, the $n$-butanol fractions displayed the best antiAChE activity, while ethyl acetate soluble fraction demonstrated the best anti-BChE activity among different solvent fractions of F. carica fruit. In the study by Orhan et al., ${ }^{38}$ the $n$-hexane and acetone extracts of leaves exhibited notable inhibition activity against both AChE and BChE. However, in our study, the aqueous extract was found to be more active than the methanol in terms of these two enzyme inhibitions. This may be due to the more polar compounds present in the aqueous extract active against $\mathrm{AChE}$ and $\mathrm{BChE}$ enzyme inhibition.

In vitro $\alpha$-glucosidase and $\alpha$-amylase enzyme inhibition activity It is known that $\alpha$-amylase and $\alpha$-glucosidase are enzymes that catalyze the hydrolysis of polysaccharides and disaccharides to monosaccharides. The inhibition of these two enzymes hinders the rapid uptake of blood glucose levels by delaying the digestion of carbohydrates. ${ }^{39}$ The results of the inhibitory activity of the $F$. carica leaf methanol and water extracts against $\alpha$-glucosidase and $\alpha$-amylase enzyme are presented in Table 2. When compared to each other, the water extract $(69.56 \%$

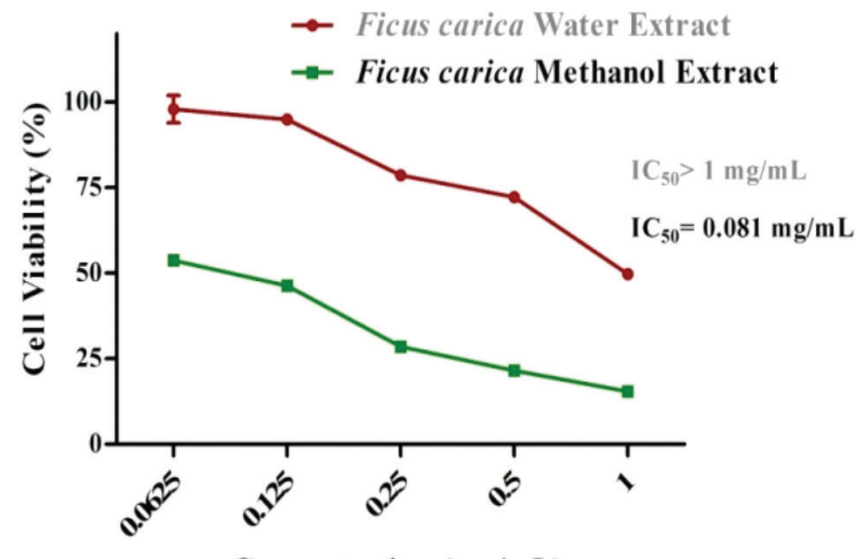

Concentration $(\mathrm{mg} / \mathrm{mL})$

Figure 2. Effects of the water and methanol extracts from $F$. carica on the viability of MDA-MB-231 cell line, after treatment with various concentrations (range: $0.065-1 \mathrm{mg} / \mathrm{mL}$ ) for $24 \mathrm{~h}$. Both extracts showed no toxicity in normal cells and $69.08 \%$ ) was found to be higher than the methanol extract (64.93\% and 67.32\%) in inhibiting $\alpha$-glucosidase and $\alpha$-amylase enzyme activity, and both extracts were found to be potential inhibitors against $\alpha$-glucosidase and $\alpha$-amylase compared with the standard antidiabetic drug acarbose (57.56\% and $58.4 \%$ ) at the same concentration $(2 \mathrm{mg} / \mathrm{mL}$ ). In a recent study, similar antidiabetic activities were reported for the ethyl acetate and ethanol extracts of $F$. carica fruit. ${ }^{39}$ In another study, the ethyl acetate extract of $F$. carica leaves showed antidiabetic activity by stimulating insulin production from regenerated pancreas beta cells. ${ }^{40}$ Similar results were reported for the water and methanol extracts of $F$. carica leaves in our study.

\section{Antimicrobial activity}

The antimicrobial activities of $F$. carica methanol and water extracts against $S$. aureus, E. faecalis, P. aeruginosa, E. coli, $K$. pneumoniae, and $C$. albicans were detected using the microdilution technique at the concentration range 0.156 to 2.5 $\mathrm{mg} / \mathrm{mL}$ (Table 3). It has been reported that the antimicrobial activity of plant extracts was evaluated as significant with MIC value less than or equal to $0.1 \mathrm{mg} / \mathrm{mL}$, moderate with $0.1<\mathrm{MIC}$ $\leq 0.625 \mathrm{mg} / \mathrm{mL}$, and weak with MIC value greater than 0.625 $\mathrm{mg} / \mathrm{mL} .{ }^{41}$ According to these criteria, the methanol extract of $F$. carica showed moderate antimicrobial activities against E. coli $(0.625 \mathrm{mg} / \mathrm{mL})$ and $S$. aureus $(0.156 \mathrm{mg} / \mathrm{mL})$ and weak antimicrobial activity against the other bacteria and $C$. albicans ( $\geq 2.5 \mathrm{mg} / \mathrm{mL}$ ). Similarly, the water extract of $F$. carica displayed moderate antimicrobial activity against $S$. aureus $(0.625 \mathrm{mg} / \mathrm{mL})$ and weak antimicrobial activity against the other bacteria and C. albicans $(\geq 2.5 \mathrm{mg} / \mathrm{mL})$.

F. carica methanol extract has been studied against various bacteria and showed moderate to strong antibacterial activity. In an in vitro study, Jeong et al..$^{42}$ reported that $F$. carica methanol extract had strong antibacterial activity on oral bacteria. In another study, Keskin et al. ${ }^{43}$ investigated the antimicrobial activity of different extracts of $F$. carica. Their study reported that the MIC values of the methanol and aqueous extracts of F. carica against bacteria and C. albicans were MIC 25-400< $\mu \mathrm{g} / \mathrm{mL}$ and MIC $200-400<\mu \mathrm{g} / \mathrm{mL}$, respectively. ${ }^{43}$ In the present study, $E$. coli and $S$. aureus were more susceptible to the methanol extract. Our results revealed that the methanol and water extracts of $F$. carica exhibited weak antimicrobial effects against other bacteria and $C$. albicans.

\section{Cell viability}

The XTT cell proliferation assay was used to evaluate the antiproliferative effects of the water and methanolic extracts of $F$. carica on MDA-MB-231 and L929 cell lines. As shown in

Table 3. Antimicrobial activity results of $F$. carica methanol and water extracts

Microorganisms and MIC values $(\mathrm{mg} / \mathrm{mL})$

\begin{tabular}{|c|c|c|c|c|c|c|}
\hline & E. coli & S. aureus & $P$. aeruginosa & E. faecalis & K. pneumoniae & C. albicans \\
\hline Water & 2.5 & 0.625 & $>2.5$ & $>2.5$ & $>2.5$ & 2.5 \\
\hline
\end{tabular}

MIC: Minimum inhibitory concantrotion 
Figure 2, the methanol extract at all concentrations significantly inhibited MDA-MB-231 cell proliferation ( $p<0.05$ ) in a dosedependent manner $\left(I C_{50}=0.081 \mathrm{mg} / \mathrm{mL}\right)$. On the other hand, concentration of $1 \mathrm{mg} / \mathrm{mL}$ of the water extract moderately decreased the cell viability $\left(I C_{50}>1 \mathrm{mg} / \mathrm{mL}\right)(p<0.05)$. However, neither extract exhibited any significant cytotoxicity on the L929 cell line in the concentrations range $(1-0.0625 \mathrm{mg} / \mathrm{mL})$.

Our cytotoxicity results clearly indicated that the methanol extract is more toxic than the water extract of $F$. carica. This may be due to the fact that the methanol extract has richer active ingredients than the water extract, as shown in Table 1. Additionally, the anticancer effects may be associated with antioxidant features due to its polyphenolic components quantity (Figure 1). To the best of our knowledge, this is the first study of the anticancer effect of fig leaf extracts on MDA-MB-231. However, different parts of $F$. carica and different extracts of fig leaf have already been found to be cytotoxic on various cancer cells such as the stomach and cervix. ${ }^{6,44}$

\section{CONCLUSION}

Overall, in this study, the components and antioxidant, antimicrobial, anticancer, enzyme inhibition, and antidiabetic effects of $F$. carica leaf methanol and water extracts were investigated. Despite the several antioxidant activities of $F$. carica leaves, to the best of our knowledge there are no reports on the comparative study of extracts with different polarity as well as other antioxidant methods such as iron chelating and ferric reducing power. Our results indicated that especially the methanol extract has strong anticancer, antioxidant, and antidiabetic activities. There is a correlation between anticancer and antioxidant activity and total phenolic content. Moreover, the richer chemical content of the methanol extract may be associated with higher biological activity. Consequently, the methanolic extract of the leaf of $F$. carica may be considered a potential therapeutic agent in cancer and diabetes mellitus. However, further studies, particularly in vivo experiments, are needed to verify these effects.

Conflicts of interest: No conflict of interest was declared by the authors.

\section{REFERENCES}

1. Manda SC, Mukherjee KP, Saha K, Das J, Pal M, Saba PB. Hypoglycemic activity of Ficus carica L. leaves in streptozotocininduced diabetic rats. Nat Prod Sci. 1997;3:38-41.

2. Alamgeer, Iman S, Asif H, Saleem M. Evaluation of antihypertensive potential of Ficus carica fruit. Pharm Biol. 2017;55:1047-1053.

3. Turkoglu M, Pekmezci E, Kilic S, Dundar C, Sevinc H. Effect of Ficus carica leaf extract on the gene expression of selected factors in HaCaT cells. J Cosmet Dermatol. 2017;16:54-58.

4. Joseph B, Raj SJ. Pharmacognostic and phytochemical properties of Ficus carica Linn - An overview. Int.J. PharmTech Res. 2011;3:812.

5. Buenrostro-Figueroa JJ, Velázquez M, Flores-Ortega O, AscacioValdés JA, Huerta-Ochoa S, Aguilar CN, Prado-Barragán LA. Solid state fermentation of fig (Ficus carica L.) by-products using fungi to obtain phenolic compounds with antioxidant activity and qualitative evaluation of phenolics obtained. Process Biochem. 2017;62:16-23.

6. Hashemi SA, Abediankenari S, Ghasemi M, Azadbakht M, Yousefzadeh Y, Dehpour AA. The effect of fig tree latex (Ficus carica) on stomach cancer line. Iran Red Crescent Med J. 2011;13:272-275.

7. Park EJ, Choi KS, Kwon TK. $\beta$-Lapachone-induced reactive oxygen species (ROS) generation mediates autophagic cell death in glioma U87 MG cells. Chem Biol Interact. 2011;189:37-44.

8. Amessis-Ouchemoukh N, Ouchemoukh S, Meziant N, Idiri Y, Hernanz D, Stinco CM, Rodríguez-Pulido FJ, Heredia FJ, Madani K, Luis J. Bioactive metabolites involved in the antioxidant, anticancer and anticalpain activities of Ficus carica L., Ceratonia siliqua L. and Quercusilex L. extracts. Industrial Crops and Products. 2017;95:617.

9. Kumkrai P, Weeranantanapan O, Chudapongse N. Antioxidant, $\alpha$-glucosidase inhibitory activity and sub-chronic toxicity of Derris reticulata extract: its antidiabetic potential. BMC Complement Altern Med. 2015;15:35.

10. Rhee IK, van de Meent M, Ingkaninan K, Verpoorte R. Screening for acetylcholinesterase inhibitors from Amaryllidaceae using silica gel thin-layer chromatography in combination with bioactivity staining. J Chromatogr A. 2001;915:217-223.

11. Tayoub G, Al-Odat M, Amer A, Aljapawe A, Ekhtiar A. Antiproliferative effects of Pancratium maritimum extracts on normal and cancerous cells. Iran J Med Sci. 2018;43:52-64.

12. Birjandiana E, Motameda N, Yassa N. Crude methanol extract of Echinophora platyloba induces apoptosis and cell cycle arrest at S-phase in human breast cancer cells. Iran J Pharm Res. 2018;17:307-316.

13. Sengupta P, Raman S, Chowdhury R, Lohitesh K, Saini H, Mukherjee $\mathrm{S}$, et al. Evaluation of apoptosis and autophagy inducing potential of Berberis aristata, Azadirachta indica, and their synergistic combinations in parental and resistant human osteosarcoma cells. Front Oncol. 2017;7:296.

14. Jeong MR, Kim HY, Cha JD. Antimicrobial activity of methanol extract from Ficus carica leaves against oral bacteria. J Bacteriol Virol. 2009;39:97-102.

15. Wang G, Wang $H$, Song $Y$, Jia C, Wang Z, Xu H. Studies on anti-HSV effect of Ficus carica leaves. Zhong Yao Cai. 2004;27:754-756.

16. Jeong MR, Cha JD, Lee YE. Antibacterial activity of Korean Fig (Ficus carica L.) against food poisoning bacteria. Korean J Food Cookery Sci. 2005;21:84-93.

17. Rashid KI, Mahdi NM, Alwan MA, Khalid LB. Antimicrobial activity of fig (Ficus carica Linn.) leaf extract as compared with latex extract against selected bacteria and fungi. JUBPAS. 2014;22:1620-1626.

18. Mawa S, Husain K, Jantan I. Ficus carica L. (Moraceae): Phytochemistry, Traditional uses and Biological Activities. Evid Based Complement Alternat Med. 2013;2013:974256.

19. Sacchetti G, Maietti S, Muzzoli M, Scaglianti M, Manfredini S, Radice M, Bruni R. Comparative evaluation of 11 essential oils of different origin as functional antioxidants, antiradicals and antimicrobials in foods. Food Chem. 2005;91:621-632. 
20. Miser Salihoglu E, Akaydin G, Caliskan Can E, Yardim Akaydin S. Evaluation of antioxidant activity of various herbal folk medicine. J Nutr Food Sci. 2013;3:1-9.

21. Re R, Pellegrini N, Proteggente A, Pannala A, Yang M, Rice-Evans C. Antioxidant activity applying an improved ABTS radical cation decolorization assay. Free Radic Biol Med. 1999;26:1231-1237.

22. Clarke G, Ting KN, Wiart C, Fry J. High correlation of 2,2-diphenyl1-picrylhydrazyl (DPPH) radical scavenging, ferric reducing activity potential and total phenolics content indicates redundancy in use of all three assays to screen for antioxidant activity of extracts of plants from the Malaysian rainforest. Antioxidants (Basel). 2013;2:110.

23. Molan AL, Mahd AS. Iraqi medicinal plants: Total flavonoid contents, free-radical scavenging and bacterial beta-glucuronidase inhibition activities. IOSR-JDMS. 2014;13:72-77.

24. Chai T, Mohan M, Ong H, Wong F. Antioxidant, iron-chelating and anti-glucosidase activities of Typha domingensis Pers (Typhaceae). Trop J Pharm Res. 2014;13:67-72.

25. Wojdylo A, Oszmianski J, Czemerys R. Antioxidant activity and phenolic compounds in 32 selected herbs. Food Chemistry. 2007;105:940-949.

26. Yang H, Dong Y, Du H, Shi H, Peng Y, Li X. Antioxidant compounds from propolis collected in Anhui, China. Molecules. 2011;16:34443455.

27. Ellman GL, Courtney KD, Andres Jr. V, Featherstone RM. A new and rapid colorimetric determination of acetylcholinesterase activity. Biochemical Pharmacology. 1961;7:88-95.

28. Kumar D, Kumar H, Vedasiromoni JR, Pal BC. Bio-assay guided isolation of $\alpha$-glucosidase inhibitory constituents from Hibiscus mutabilis leaves. Phytochem Anal. 2012;23:421-425.

29. Kumar D, Gupta N, Ghosh R, Gaonkar RH, Pal BC. $\alpha$-Glucosidase and $\alpha$-amylase inhibitory constituent of Carex baccans: Bio-assay guided isolation and quantification by validated RP-HPLC-DAD. J Funct Foods. 2013;5:211-218.

30. Eloff JN. A sensitive and quick microplate method to determine the minimal inhibitory concentration of plant extracts for bacteria. Planta Med. 1998;64:711-713.

31. Konyalıoğlu S, Sağlam H, Kıvçak B. $\alpha$-Tocopherol, flavonoid, and phenol contents and antioxidant activity of Ficus carica leaves. J Pharm Biol. 2005;43:683-686.

32. Harzallah A, Bhouri AM, Amri Z, Soltana H, Hammami M. Phytochemical content and antioxidant activity of different fruit parts juices of three figs (Ficus carica L.) varieties grown in Tunisia. Ind Crops Prod. 2016;83:255-267.

33. Teixeira DM, Canelas VC, de Canto AM, Teixeira JMG, Dias CB. HPLC-DAD quantification of phenolic compounds contributing to the antioxidant activity of Maclura pomifera, Ficus carica and Ficus elastica extracts. J Anal Lett. 2009;42:2986-3003.

34. Ali B, Mujeeb M, Aeri V, Mir SR, Faiyazuddin M, Shakeel F. Antiinflammatory and antioxidant activity of Ficus carica Linn. leaves. Nat Prod Res. 2012;26:460-465.

35. Halliwell B, Gutteridge JM. Oxygen toxicology, oxygen radicals, transition metals and disease. Biochem J. 1984;219:1-14.

36. Szeto YT, Tomlinson B, Benzie IF. Total antioxidant and ascorbic acid content of fresh fruits and vegetables: implications for dietary planning and food preservation. Br J Nutr. 2002;87:55-59.

37. Ahmad S, Bhatti FR, Khaliq FH, Younas T, Madni MA, Latif A. In vitro enzymatic investigation of Ficus carica (Fruit). Pak. J. Pharm. Sci. 2016;29:1541-1544.

38. Orhan IE, Ustün O, Sener B. Estimation of cholinesterase inhibitory and antioxidant effects of the leaf extracts of Anatolian Ficus carica var. domestica and their total phenol and flavonoid contents. Nat Prod Commun. 2011;6:375-378.

39. Mopuri R, Ganjayi M, Meriga B, Koorbanally NA, Islam MS. The effects of Ficus carica on the activity of enzymes related to metabolic syndrome. J Food Drug Anal. 2018;26:201-210.

40. Stephen Irudayaraj S, Christudas S, Antony S, Duraipandiyan V, Naif Abdullah AD, Ignacimuthu S. Protective effects of Ficus carica leaves on glucose and lipids levels, carbohydrate metabolism enzymes and $\beta$-cells in type 2 diabetic rats. Pharm Biol. 2017;55:1074-1081.

41. Kuete V. Potential of Cameroonian plants and derived products against microbial infections: A review. Planta Med. 2010;76:14791491.

42. Jeong MR, Kim HY, Cha JD. Antimicrobial activity of methanol extract from Ficus carica leaves against oral bacteria. J Bacteriol Virol. 2009;39:97-102.

43. Keskin D, Ceyhan Guvensen N, Zorlu Z, Ugur A. Phytochemical analysis and antimicrobial activity of different extracts of fig leaves (Ficus carica L.) from West Anatolia against some pathogenic microorganisms. J Pure Appl Microbiol. 2012;6:1105-1110.

44. Khodarahmi GA, Ghasemi N, Hassanzadeh F, Safaie M. Cytotoxic effects of different extracts and latex of Ficus carica L. on HeLa cell line. Iran J Pharm Res. 2011;10:273-277. 